\title{
A SANTA SÉ E O ESTADO DA CIDADE DO VATICANO: distinção e complementaridade
}

Salmo Caetano de Souza'

\begin{abstract}
Resumo:
O presente artigo quer explicar como o papa ou a Santa Sé - que, aliás, são expressões sinônimas e manifustam a mesma realidade - se apresenta e, por conseguinte, atua, diplomaticamente. no contexto da Comunidade das Nações Unidas (ONU). Em outras palavras, este artigo procura mostrar a relação que existe entre a Santa Sé e a sua Ação Diplomática no seio dos Estados-membros que compôem o referido Organismo Internacional.
\end{abstract}

Palavras-chave: Direito Canônico. Santa Sé. Estado da Cidade do Vaticano. Tratado de I.atrão.

\begin{abstract}
:
This paper delineates how the pope and the Holy See - synonymous entities and as such expressing the onc and the same reality - function within the international community. This explanation is elicited especially from their diplomatic action within the Community of Countries at the United Nations (UN). The action of the pope and the Holy See through the diplomatic activity in the countries within community serves as a backdrop for this elucidation.
\end{abstract}

Keywords: Canon Law. Hole Sec. City of Vatican State. Treaty of I atran.

\section{Introdução}

A Santa Sé e o Estado da Cidade do Vaticano são dois conceitos que, ao longo da história e até hoje em dia se misturam, se confundem e, às vezes, se fundem, sendo tomados um pelo outro no entendimento geral, sobretudo pela mídia e até mesmo pelos próprios fiéis católicos. A situação fica pior quando a esses dois conceitos se acrescenta um terceiro, ou seja. o de Igreja Católica. Aí, então, não se sabe quem é quem. O mais comum é a associação entre os dois últimos conceitos, ou seja, o "Vaticano". como é familiarmente chamado o Estado da Cidade do Vaticano, e a Igreja Católica. onde aquele primeiro aparece como o centro de poder ou de direção (o Papa) dessa última. Mas. poucos sabem onde se encaixa nessa relação triangular a Santa Sé.

Doutor em Direito Internacional Público pela Faculdade de Direito da Universidade de São Paulo (USP), Sacerdote da Arquidiocese de São Paulo, doutor em Direito Canônico pela Pontificia Universidade São Tomás de Aquino, de Roma. 
O objetivo deste artigo é mostrar como se dá a articulação entre estas três figuras, evidenciando que tal relação se dá, ao mesmo tempo, através de dois aspectos: distinção e complumentaridade.

\section{Quem é a Santa Sé'}

Segundo o Cânon 361, do Código de Direito Canônico de 1983, o termo Santa Sé ou Sé Apostólica tem dois sentidos diferentes, ao afirmar o quanto segue:

Sob a denominação de Sé Apostólica ou Santa Sé, neste Código, vem não-só o Romano Pontifice, mas também, a não ser que pela natureza da coisa ou pelo contexto das palavras se depreenda o contrário, a Secretaria de Estado, o Conselho para os Negócios Públicos da Igreja e os demais organismos da Cúria Romana. ${ }^{2}$

O primeiro sentido é amplo e geral e, o outro. estrito e especial.

No sentido amplo e geral, o nome Santa Sé ou Sé Apostólica compreende não-só o Romano Pontífice, “(...) mas, também, a não ser que pela natureza da coisu ou pelo contexto das palavras de depreenda outra coisa, a Secretaria de Estado" e outras instituições da Cúria Romana. ${ }^{3}$

No sentido estrito e especial, o termo Santa Sé ou Sé Apostólica designa somente o Romano Pontífice, quer dizer, o Ofício ou a Função do Romano Pontífice; ou, em outras palavras, designa o Papado, o Primado Romano e a sua pessoa.

Para us propósitos desse artigo, convém ressaltar mais o último sentido do termo Santa Sé, ou seja. o seu significado estrito e especial. vale dizer. a pessoa t a função do Romano Pontífice, que aparece aqui enquanto o titular em exercício da Santa Sé, enquanto Órgão Supremo de direção da Igreja. A Cúria Romana, segundo o sentido amplo, é só um órgão auxiliar do papa no governo universal da Igreja. Este cânon coloca então o papa como Cabeça da Igreja e, conseqüentemente, como detentor da Suprema Autoridade da mesma. ${ }^{4}$

O conteúdo desse item se encontra fartamente desenvolvido no Segundo Capitulo da nossa tese de doutorado apresentada ao Departamento de Direito Internacional da Faculdade de Direito da Universidade de São Paulo. em 25/10/2004, intitulada "A Mediação da Santa Sé na Mediação do Canal de Beagle"

2 CODIGO de Direiso Canônico (CIC). Tradução em língua portuguesa da Conferência Nacional do Brasil, São Paulo: Loyola, 1983.

3 Cân. 361, CIC 1983.

- Note-se, porém, que a Suprema Autoridade da Igreja Católica tem como destinatários. além do papa, o Colégio dos Bispos. Trata-se, portanto, de dois sujeitos inadequadamente distintos, que atuam em dois modos: um pessoal (o Papa) e o outro colegial (Colégio dos Bispos) (Cânon 336, ClC). 
A Igreja Católica, por sua vez, sob o aspecto jurídico, surge como sendo uma comunidade de fí autônoma, socialmente organizada e fundada por Deus através de Cristo e, portanto, independente de qualquer poder humano, quer dizer, soberana, cujo exercício da soberania - é uma soberania espiritual - corresponde ao papa. Note-se. portanto, que a Igreja e o papa são fenômenos que nasceram simultaneamente e inseparavelmente, mas com papéis distintos, se bem que complementares. por vontade de seu fundador. Jesus Cristo. O papa foi posto pelo Cristo como Cabeça da lgreja, como afirma Rafael Llano Cifuentes:

Em primeiro lugar. Jesus escolheu doze homens entre seus discípulos com o intuito de prepará-los para um especial ministério apostólico de direção. ${ }^{5}$ é a eles que Cristo diz: "Quem voz recebe, a mim recebe, quem me recebe, recebe a quem me enviou" " Cristo, porém, não se limita a escolhêlos, confere-lhes uma autoridade, um poder de governar: "Em verdade vos digo, que tudo o que vós ligardes na terra será ligado no Céu e tudo o que desligardes na terra será desligado no Céu" " Servindo-se desta metáfora tão comum na linguagem rabinica, "ligar e desligar" que significa proibir ou permitir, Cristo entendia dar a seus discipulos uma negável autoridade governativa e um poder supremo de jurisisdição. que abarca a possibilidade de condenar e de excluir da Igreja qualquer dos seus membros. ${ }^{8}$

Essa autoridade prossegue o referido autor - ele a centraliza numa pessoa concreta, quando diz:

Tu és Pedro e sobre esta pedra edificarei a minha Igreja e as portas do Inferno não prevalecerão contra ela. Dar-te-ei as chaves do Reino dos Céus e tudo quanto ligares na terra será ligado nos Céus e tudo quanto desligares na terra será desligado nos Céus. ${ }^{9}$

A pedra fundamenial, atirma o referido autor, base jurisdicional da Igreja, tem, além do poder de atar e desatar, aquele "poder das chaves", que sempre se havia considerado -. inclusive em outros lugares paralelos do Antigo Testamento - como símbolo do poder soberano. Pedro - e os seus sucessores, a quem se entregaram as chaves do reino dos céus - como tradicionalmente se faz com aquele a quem se outorga o

\footnotetext{
LI ANO CIFUENTES, R. Cursu de Direito ('anônico. São Paulo: Saraiva. 1971. p. 2.

Mc., 16. 16; Mt. 16, 18-20: LLANO CIFUENTES, R., op. cit., p. 25.

Vt. 1, 2-9; Mc. 3. 13-19; Lc., 6, 13-16: Jo., 10. 2-4: LLANO CIFUENTES, R., op. cil., p. 25.

Mt. 18, 18: LLANO CIFUENTES. R., op. cit., p. 25.

Mt. 16, 16: LLANO CIFUENTES. R., op. cit., p. 25.
} 
domínio duma cidade ou dum reino - tem o poder supremo da Igreja, reino de Deus na terra.

Mais ainda, acrescenta o mencionado autor Cristo, como que querendo pôr em relevo o caráter social e hierárquico da Igreja, no ambiente de solenidade de que estava revestida a sua despedida. antes da Ascensão aos Céus, disse aos Apóstolos:

Foi me dado todo o poder no céu e na terra: ide. pois, e ensiriai a todas as gentes, batizando-as em nome do Pai, do Filho e do Espírito Santo, ensinando-as a observar todas as coisas que vos tenha mandado até a consumação dos séculos. ${ }^{10}$

Recebei o Espírito Santo: aqueles a quem vós perdoardes, os pecados serIhes-ão perdoados, e aqueles a quem vós o retiverdes, ser-lhes-ão retidos. "

A interpretação mais estrita destes textos, assevera o referido autor. referendada por numerosos estudos escriturísticos, deixa claro que Cristo, de um modo explícito, quis a Igreja como sociedade estabelecida com um poder soberano hierarquicamente constituido. ${ }^{12}$

Ora, por estar constituído essencialmente pelo Ofício do Romano Pontífice, correspondem a Santa Sé todos os direitos e prerrogativas que competem ao Romano Pontífice:

1. enquanto cabeça do corpo eclesial, o poder do regime ordinário, supremo, pleno, imediato e universal que the é próprio; ${ }^{13}$

2. enquanto soberano temporal do Estado da Cidade do Vaticano; ${ }^{14}$

3. enquanto Patriarca do Ocidente, Primaz da Itália, Metropolita da Província Romana e Bispo de Roma, e com o conjunto dos órgãos que compõem o Oficio Primacial, tais como dicastérios, tribunais e ofícios romanos, no seu sentido amplo, ou seja, a Cúria Romana.

A Santa Sé vem a ser, então, de forma histórica e concreta, cuja realidade objetiva não pode ser negada, a Suprema Direção ou o Organismo Supremo de Direção e Representação da Igrcja Católica. Não importa se a direção é exercida pessoalmente pelo papa ou, em seu nome, pelas instituições centrais colaboradoras dele, como, por exemplo, a Cúria romana.

10 Mt. 28, 18-20: LI ANO CIFUENTES, R., op. cit, p. 25.

$"$ Jo. 19,20: LLANO CIFUENTES, R., op. cit., p. 25.

12 LLANO CIFUENTES, R., op. cil., p. 25-26.

13 Cân. 331. ClC 1983.

14 Desse tema tratarcmos no item 2: "Quem è o Estado da (idade do Vaticanu" 
O cân. 113, § $1^{\circ}$ do Código de Direito Canônico de 1983, afirma o seguinte: “A Igreja católica e a Sé Apostólica são pessous morais pela própria ordenação divina ..." Is

A Santa Sé e a Igreja Católica são pessoas morais, no sentido em que elas não recebem sua personalidade e sua existência jurídica de algum ordenamento temporal e territorial, mas, sim, diretamente de seu fundador, Jesus Cristo: ambos são pessoas chamadas de pré-juridicas, porque é pessoa de natureza espiritual, religiosa e humanitária, isto é, emana de um Direito inerente a sua própria natureza, ou seja, que não procede dos meios institucionais característicos do regime democrático. ${ }^{16}$ A Santa Sé e a Igreja Católica constituem uma realidade de natureza espiritual, porque postas de pé pelo próprio Cristo, seu fundador e promulgador, através do Ministério Petrino. A sucessão legítima direta e ininterrupta desse ministério que Cristo confiou a Pedro atravessa a história através dos séculos. chegando até nós na pessoa do atual Pontífice. Bento XVI, que é o $265^{\circ}$ papa na linha da sucessão legítima. A Santa Sé, assim. é uma realidade dinâmica na historia, porque ela se faz presente em cada momento da mesma, através de seu legítimo titular.

Assim, os direitos e prerrogativas da Santa Sé ou da Suprema Autoridade da Igreja Católica são inerentes a sua própria missão espiritual no mundo e, enquanto tal, foi reconhecida pelo ordenamento positivo internacional. ${ }^{17}$

Tal reconhecimento internacional da especificidade da Santa Sé data de 380 d.C., quando o Imperador Romano Teodósio promulgou o Edito de Tessalônica Cunctos Populos, através do qual estabelecia que a religião cristã era oficialmente reconhecida como a religião do Estado. A partir de então. a Santa Sé participa ativamente da vida da Comunidade Internacional.

Assim, a especificidade da natureza e da missão espiritual da Santa Sé, bem como a sua qualidade de Pessoa Jurídica de Direito Internacional Público, vem acontecendo através de um costume e praxe internacional antiqüíssimos, ou seja, desde 380 d.C. Dessa forma, pode-se d:zer que a experiência internacional da Santa Sć antecede aquela dos Estados em quase quinze séculos, considerando o nascimento dos mesmos a partir de 1648, com o Tratado de Vestfália.

\footnotetext{
CIC 1983.

Vale dizer, do Direito Divino.

17 No sentido da Convenção de Montevidéu sobre os direitos e deveres dos Estados, aprovada em 26 de dezembro de 1933, na Sétima Conferência Internacional Americana, que declara o seguinte: Artigo 6" - "O rcconhicimento de um Estado apenas signilica que aquele que o recunhece aceita a personalidade do outro, com todos os direitos e deveres determinados pelo direito internacional. Trata-se de um reconhecimento no suntido declaratório, ou seja, simplesmente constata a preexistència do Estado ora reconhecido"
} 
Assim. desde o século IV, a Santa Sé nunca deixou de ser um membro ativo da Comunidade internacional.

Hoje em dia, a participação da santa Sé nos organismos internacionais se dá por cinco maneiras: Observador Permanente; Observador em Base Informal; Membro; Hóspede de Honra: Delegado Especial.

Assim. é a Santa Sé que participa de conferências e subscreve ou adere a convênios internacionais. exercendo os mesmos direitos que os outros Estados-membros, em perfeita paridade com todos eles. depcndendo do status da sua participação. Inclusive, conforme o Protocolo de Aquisgrana e a Convenção de Viena de $1961^{18}$ sobre Relações Diplomáticas, na qualidade de membro e de observador permanente, reconhece-se aos seus representantes a precedência como Decano do Corpo Diplomático. ${ }^{19}$

Desta forma, foram sendo subscritos os documentos internacionais, tanto em nome da Santa Sé quanto em nome do Estado do Vaticano. Porém, a partir de 1957, é a Santa Sé que assume exclusivamente a dupla representação, tanto do Estado da Cidade do Vaticano quanto da Igreja Católica. É o que se entende a partir da seguinte comunicação da Secretaria de Estado da Santa Sé ao Secretário Geral das Nações Unidas, em 1957:

(...) para dissipar algumas incertezas que vinham se manifestando a ruspeito do tema das relações entre a Secretaria de Estado ¿ a Secretaria das Nações Unidas, esta, através de uma comunicação ${ }^{20}$ ao Sucretário Geral Dag Hammerskjöld, ${ }^{21}$ pela qual a Secretaria de Estado de Sua Santidade quis precisar que as relações que esta mantém com a Secretaria das Nações Unidas se entendam estabelucidas entre a Santa Sí e as Nações Unidas, e que as delegações que a Secretaria de Estado possa vir a acreditar perante a Organização das Nações Inidas são delegações da Santa Sé e devem ser designadas de agora em diante como tais. ${ }^{22}$

A exceção de um minguadíssimo número de Estados, a Santa Sé mantém relações diplomáticas com todos os outros membros das Nações Unidas (191 membros).

A Santa Sé mantém relações diplomáticas também com a União Europíia c com a Soberana Ordem Militar de Malta (SOMM), bem como tem relações de natureza

\footnotetext{
1s Assinada em 18 de abril de 1961. Entrada em vigor em 24 de abril de 1904. Apruvada pelo Decreto L.egislativo n. 1.003, de 1964. Ratificada em 23 de fevereiro de 1965. Depósito de instrumento de ratificação pelo Decreto n. 56.435 de 8 de junho de 1965 (D.O.U, de 11 de junho do mesmo ano).

19 SALVADOR, C.C.; EMBIL. J.M.U. Dicıonário de Direito Canônico. São Paulo: Loyola, 1983. p. 677.

20 Leg. 34-1, de 29/10/1959.

21 Nota n. 6.752/57, de 16/19/1957.

22 SALVADOR, C.C.; EMBIL, J.M.U.. op. cit., p. 677.
} 
especial com a Federação Russa e com a Organização para a Libertação da Palestina (OLP).

Participa, também, de diferentes organizações e organismos intergovernamentais internacionais.

O órgão ou dicastério propriamente encarregado de auxiliar o papa na sua relação com os Estados é a Secretaria de Estado. O papa João Paulo II. em 28 de junho de 1988, promulgou a Constituição Apostólica "Pastor Bonus". pela qual, reformando a Cúria Romana, dividiu a Secretaria de Estado em duas Secções: a Secção dos Assuntos Gerais, ou Primeira Secção, e a Seç̧ão das Relações com os Estados, ou Segunda Secção, na qual confluiu o Conselho dos Assuntos Públicos da Igreja e que é. propriamente falando, encarregada das relações diplomáticas da Santa Sé com os Estados, incluindo a estipulação de concordatas ou acordos semelhantes, representação da Santa Sé junto a Organismos e das Conferencias Internacionais, além da provisão de Bispos para as Igrejas Particulares e de tratados internacionais com a Santa Sé. ${ }^{23}$

\section{Justificação ou Razões da Diplomacia da Santa Sé}

1) Estrutura organizativa claramente universal da Igrcja Católica Romana (nãosupernacional, mas, antes, transnacional): é a única confissão religiosa que tem acesso às relações diplomáticas.

2) Personalidade jurídica internacional do Pontifício Romano: que passa a gozá-la a partir da sua eleição em conclave.

3) Papado: a partir do século IV. o Papado tornou-se o centro das nações do Ocidente cristão: é suficiente pensar na época da Res Publica Christiana, ou então no período em que o Sumo Pontífice pronunciava arbitragens e promovia a paz em nome do jus gentium christianorum. ${ }^{24}$ Poder-se-ia recordar, ainda, as suas mediações internacionais nas disputas entrc a Espanha e Portugal, relativas aos territórios do Novo Mundo. ${ }^{25}$

4) Personalidade jurídica internacional da Santa Sé: ao longo dos séculos, a subjetividade internacional da Santa Sé sobreviveu às tormentas da reforma protestante, da revolução francesa e da anexação italiana, a tal ponto que, graças à personalidade que Ihe é reconhecida, a Santa Sé pode exercer, mesmo nos dias de hoje, uma presença ativa nas relações internacionais, de modo particular no contexto da diplomacia bilateral e multilateral. É fá-lo através de uma rede de relações diplomáticas, que a põe

23 Para aprofundamento, consulte nossa tese doutoral, op. cit., p. 124-129.

24 ZlMMERMANN, M. Organisation internationale (Fin du Moyen Age). Recueil des Cours. v. 2. p. 327, 1933.

25 Para aprofundamento, consulte: BRUNO, J.L. Mediaciones papales en la historia. Montcvideo: Ministerio de Rilaciones Extcriores, 1981, p. 48-64; também a nossa tese doutoral, op. cit., p. 132-136. 
em contato com os seus representantes junto à Organização das Nações Unidas e de outras organizações governamentais.

5) A ação diplomática internacional da Santa Sé se diferencia daquela dos Estados, pois, enquanto aqueles têm ambições de poder político, material, aquela tem pretensões de poder espiritual, moral e de influência, mas "inspirada somente pelo desejo de prestar serviço a todos" 26 Essencialmente falando. A Santa Sé constitui, assim, um sujeito soberano de direito internacional, mas de natureza claramente religiosa e humanitária. Por conseguinte, a sua "estratégia" consiste, sobretudo, em realçar e em dar voz à consciência das pessoas e dos povos em geral. É por este motivo, e não por ambições de poder material, que ela mantém um diálogo franco e cordial com os governantes. Dirigindo-se às consciências, ela promove os princípios, sem os quais não se pode falar de uma "Comunidade de Nações"

Em outras palavras, a concepção que a Santa Sé nutre pelo poder revela uma visão diferente do mesmo, por um lado, quanto à eficácia e, por outro lado, quanto à natureza:

- quanto à eficácia: não se baseia na coação da força para a sua observância, mas sim na força da consciência;

- quanto à natureza: baseia-se nos valores morais perenes e comuns a todos os seres humanos, não por serem valores católicos. mas universais.

Princípios que Constituem uma Espécie de Corpus da Moral Internacional da Santa Sé:

1) Em primeiro lugar, a centralidade da pessoa humana e, por conseguinte. dos seus direitos: a Santa Sé se compromete a recordar e, se for necessário, a defender o primeiro de todos os direitos humanos - o direito à vida, em todas as fases do desenvolvimento biológico da pessoa, até a sua morte natural (...). ${ }^{27}$ Em seus contatos com os responsáveis da comunidade internacional, a Santa Sé nunca cessou de recordar que a vida constitui um dom que provém do Outro - Deus - e que, portanto, é sagrada (...). A firmando isso, ela deseja falar também em nome de todos os cristãos e, inclusivamente, em nome dos homens de boa vontade. Além disso, ela quer

26 CONCÍlIO VATICANO II, Parte II, Cap. V, n. 89: “(...) a Igreja deve estar absolutaminte presente na comunidade dos povos, para fomentar e despertar a cooperaçâa entre os homens: e isto lanto por suas instituiçóes públicas, como cinda pela plı̀na e sincera colaboração de todos os cristāos. inspirada somente pelo desejo de prestar serviços a todos"

27 Aquela que decorre por causas naturais, biológicas e internas ou exismas, por violência acidental (um desastre de carro, por exemplo), excluindo assim qualquer possibilidade de antecipação intencional da morte pela intervenção do homem, como, por exemplo, a eutanásia, justificando-a pretensamente cum razões de miscricórdia. 
sublinhar o fato de que o direito à vida é o fundamentu de todos os outros dircitos que lhe estão a peito: o direito à liberdade, de consciência e de religião, à educação, ao trabalho, ao desenvolvimento humano, etc. Os direitos fundamentais não derivam dos Estados, nem de qualquer outra autoridade humana, mas da própria pessoa (...) e, por isso, são universais, invioláveis e inalienáveis.

1.1) Liberdade de consciência e de religião: não apenas como liberdade de culto, mas também como possibilidade para os crentes participarem na vida social e política do país de que são cidadãos, mas sempre como membros de uma comunidade de fé (...). Quando a liberdade de religião é suprimida, na realidade passam a ser ameaçadas todas as outras liberdades fundamentais.

Em síntese, pode-se afirmar que a Santa Sé se opõe a qualquer visão unidimensional do homem e propõe outra, que é aberta aos seus componentes individuais, sociais e transcendentes.

2) Promoção e salvaguarda da paz: a Santa Sé rejeita a gucrra como meio de solução não-pacítico para as controvérsias entre os povos. Por ocasião da recente crise iraquiana, o papa João Paulo II e os seus colaboradores recordaram que cada um dos Estados tem o dever de proteger a sua própria existência c liberdade, com meios proporcionais, contra um injusto agressor. Para além do caso da legítima defesa, que justifica o recurso às armas, para resolver as contendas devem preferir-se sempre os instrumentos do diálogo e da mediação, como a arbitragem de terceiros, que sejam imparciais, ou de uma autoridade internacional munida de suficientes poderes. Com efeito, a experiência tem mostrado que a violência gera mais violência. Deve-se recordar a exclamação do papa durante a primeira Guerra do Golfo: “A guerra é uma aventura sem rctorno" Ou, ainda, há poucos meses: "A guerra é sempre uma derrota para a humanidade"

Por conseguinte, a Santa Sé sempre encorajou os esforços realizados com vista a alcançar um desarmamento efetivo, que vá além da dissuasão, fundamentado no equilibrio do terror. Para apoiar moralmente o compromisso nesse sentido, em 1971 ela não hesitou em assinar o Tratado de Não-Proliferação Nuclear; em 1993, aderiu au Tratado Contra a Produção, o Desenvolvimento e o Uso das Armas Químicas; e em 1997. aderiu ao Tratado que pró́be as minas anti-homem. E tudo isso para encorajar uma autêntica cultura da paz.

3) Não há paz sem justiça: a paz é muito mais do que a ausência de conflitos. Fla fundamenta-se numa ordem sucial e internacional, assenta sobre o direito e a justiça. Cada país tem o dever se assegurar aos seus cidadãos a satisfação de algumas necessidades fundamentais, como, por exemplo, a alimentação, a saúde. o trabalho. a 
moradia e a educação. "A Igreja contribui para alargar o campo de ação da justiça e do amor, no interior de cada um dos paises entre todas as nações" 28

4) Princípios consuetudinários do Direito Internacional e as convenções: a Santa Sé está também convencida de que cada um dos países tem o dever de respeitar tais princípios e convenções a que livremente aderiu. Sem direito não existe ordem e, muito menos, liberdade e paz.

5) Guerra preventiva: durante a crise iraquiana, a Santa Sé afirmou que nãocompartilhava de tal princípio inventado ad hoc e pediu que se respeitasse o conteúdo da Carta das Organizações das Nações Unidas. de modo particular o seu Capítulo VII, que define os critérios de comportamento em caso de ameaças ou de agressões contra a paz. Com efeito, a comunidade internacional elaborou e codificou uma série de direitos e deveres que já constituem uma parte do patrimônio comum da humanidade. À custa de sacrifícios enormes, a comunidade internacional adquiriu um corpus jurídico consistente e pormenorizado que, se tivesse sido aplicado nestes últimos anos, em conformidade com a antiga máxima latina pacta sunt servanda, teria poupado muito derramamento de sangue e evitado numerosas crises internacionais.

6) Direito internacional: a Santa Sé sempre manifestou o seu apreço por tal direito e freqüentemente colaborou para a redação de convenções que, muitas vezes, o renovaram. Por exemplo, o dever das intervenções humanitárias ou os direitos das minorias, exceções essas ao Princípio da Não-Intervenção ou Ingerência. ${ }^{29}$

7) Organização das Nações Unidas: os Papas nunca hesitaram em exprimir a sua estima por essa Instituição, afirmando-a como “... o maior de todos os instrumentos de síntese e de coordenação da vida internacional" realçando que a sua atividade condiciona a cultura e a ética intemacionais, e desejando que “... essa Organização (...) se eleve cada vez mais, do estádio de uma instituiçâao insensivel de tipo

28 Gaudium et spes, 76.

29 WILSON, L.G. A prática e o stalus da intervenção e da não-intervenção no direito internacional contemporâneo. Revista de Informação Legislativa. Brasilia, v. 20, n. 79, 1983, p. 257: “... a normu da nãointervenção, o corolário da soberania. é ainda uma parte do direito internacional e é aceito pela comundade intcrnacional: os Estados geralmente cumprem a norma, apesar da impressão ser freqüentemente ao contrario. Em decorrência das expectativas da comunidade. os Estados acham importante e necessario justificar cuidadosamente, em termos legais, suas intervençòes como sendo ¿xceções à não-intervenção" Ibidem, p. 258: "... inobstante a tendência intervencionista, a mudança de contexto e conteudo das relações internacionais e os ataques ao sistema de Estado e soberania dominantes. a norma da não-intervenção é ainda largamente aceita e praticada" Para aprofundamento, consulte: DAVILLA. A. Humanitarian intervention in public international law. Geneva: Institut Universitaire de Hautes Etudes Internationales, Dipl. N. 96, 1967; REISMAN, M. \& McDOUGAL. M. Humanitarian intervention to protect the Ibos. In: LILI ICH, R.N. (ed.). Humanitarian intervention and the United Vutions. Charlottesville: University Press of Virginia, 1973. p. 167-195. 
administrativa, ao nivel de um centro moral em que todas as nações do mundo se' sintam em casa, desenvolvendo a sua consciência comum de serem, por assim dizer, uma familia de nações (...). Por sua natureza, a familia é uma comunidade fundamentada na confiança recíproca, na ajuda mútua e no respeito sincero: numa familia autêntica não existe o dominio dos mais fortes: pelo contrário, os membros mais frágeis são, em virtude da sua debilidade, duplamente acolhidos e servidos" 30 Somente uma rigorosa aplicação do direito, por parte de todos e em cada uma das circunstâncias, pode impedir que o indivíduo mais frágil se torne vítima da má vontade, da força e das manipulações dos mais fortes. Por conseguinte, a Santa Sé compromete-se a fazer com que a força da lei prevaleça sobre a lei do mais forte.

8) Democracia: a Santa Sé nutre apreço pela democracia. A paz e a convivência civil são sempre gravemente ameaçadas pelas diferentes expressões de um poder totalitário, pela obsessão da segurança, pela ideologia. pela procura de privilégios para determinadas categorias de cidadãos. E o século que há pouco chegou ao seu termo ensina-os com eloqüência (...). Democracia significa sempre participação e responsabilidade, direitos e deveres.

9) Isto não-significa que a Santa Sé opte ou prefira o regime democrático ou qualquer outro regime ou ideologia política. Significa, apenas, que a Santa Sé reconhece os valores increntes a essa ideologia política.

A Igreja, na verdade, é uma teocracia, ou seja, tem a sua origem na vontade divina. Assim, teocracia e democracia são dois princípios antagônicos e divergentes na sua origem e na sua natureza. A teocracia é de natureza teológica, enquanto que a democracia é de natureza sociológica. A democracia tem origem no consenso numérico da maioria, ao passo que a teocracia tem a sua origem na vontade divina da autoridade. A Igreja Católica, porém, tem elementos na sua estrutura semelhantes ao princípio democrático, mas de natureza teológica, tais como o conceito de comunhão e de colegialidade.

10) Mensagem profética: o papa João Paulo II está profundamente convicto de quc os males que afligem a sociedade internacional contemporânea não são uma fatalidade. Na sua opinião, cada um de nós pode desenvolver em si mesmo a potencialidade da fé, de respeito pelo próximo, de dedicação ao serviço de outros e, portanto, resolver situações de injustiça e de conflito. Tudo pode mudar, afirma o Pontífice Romano. Isso depende de cada um de nós. Cada qual pode desenvolver em si o seu potencial de fé. de honradez, de respeito pelo próximo, de dedicação ao serviço dos outros.

11) Os principais imperativos da Santa Sé poderiam ser assim resumidos:

30 JOÃO PAL LO II, em sua últimá visita, em 1995. por ocasião do $50^{\circ}$ aniversário da fundação da UNL: 
- Sim à vida.

Respeito pelo direito.

Dever da solidariedade.

Não à morte.

- Não ao egoísmo.

Não à guerra.

Em síntese, "a razão de ser da Santa Sé" - conclui o papa João Paulo II "no seio da comunidade das nações consiste em constituir a voz que a consciência humana espera, sem por isso diminuir a contribuição das outras tradições religiosas" 31

Em outras palavras, esse serviço da consciência é exclusivamente a única ambição da diplomacia pontifícia: convencer as pessoas que são responsáveis pelas sociedades de que a violência. o medo, a repressão, o mal e a diferença não podem ter a última palavra.

A Santa Sé é pessoa moral, religiosa ou espiritual, porque foi fundada diretamente por Deus, através de Cristo Jesus. Assim, ela emana de um Direito inerente a sua própria natureza, ou seja, que não procede dos meios institucionais legais característicos do regime democrático; vale dizer, a Santa Sé é criação do Direito Divino. Por isso, a Santa Sé é, também, pré-jurídica. pois surge antes mesmo da própria intervenção do direito positivo, a partir do qual nasce a pessoa jurídica. É humanitária. porque trabalha pelo bem da humanidade, cooperando para resgatá-la da imensidade de sofrimentos e dissensões em que se encontra, defendendo que a organização da vida dos homens se faça segundo padrões qualitativos progressivos de justiça e de amor. É a Suprema Autoridade da Igreja Católica e do Estado da Cidade do Vaticano.

No plano nacional, a Santa Sé zela pelos interesses da Igreja Católica junto dos Governos de cada Estado onde se faz. presente e junto ao Episcopado estabelecido no mesmo.

No plano internacional, a Santa Sé é constituída essencialmente pelo Ofício do papa e seus direitos e prerrogativas derivados da sua Soberania Espiritual, que é a sua qualidade primordial, que constitui a verdadeira razão de ser do Papado e que fundamenta a sua Personalidade Juridica de I ireito Internacional Público, reconhecida, aliás, desde 380 d.C., momento em que a Igreja Católica tornou-se religião oficial do Império romano $\mathrm{e}$, assim, começou a participar ativa e ininterruptamente da vida internacional das nações - e, enquanto tal, é dotada de direito de legação, vale dizer, a Santa Sé é um ser diplomático, cuja finalidade. além de ser a de se empenhar para o bem da humanidade, é

31 JOÃO PAULO II. Discurso ao ( :orpo Diplomático acreditado junto à Santa Sé. de 1995. 
também a de colaborar ativa a positivamente para a consolidação da Comunidade Internacional e pela manutenção da paz entre os homens.

Enquanto instituição dotada de atividade diplomática, a Santa Sé possui um conjunto de órgãos ou uma estrutura racional para lidar com assuntos das suas relações com outras entidades a ela assemelhadas, isto é, reluções exteriores, melhor dizendo, externas a um ordenamento juridico nacional. Isso significa que a Santa Sé tom uma política exterior própria para lidar com as questões internacionais.

\section{Quem é o Estado da Cidade do Vaticano}

\subsection{A Questão Romana (1870)}

Segundo Hildebrando Accioly, ${ }^{32}$ antes de 1870, o papa englobava em sua pessoa o poder espiritual de Chefe da Igreja Católica e o poder temporal do Chefe dos Estados Pontifícios. Como soberano temporal, a sua autoridade era comparável a de qualquer outro Chefe de Estado; exercia-se plenamente, dentro dos limites dos seus Estados. Por isso mesmo, nunca se discutiu ou se pôs em dúvida a sua personalidade internacional. $\hat{E}$ inegável, todavia, observa o autor na obra citada, que o poder temporal do Chefe da Igreja nunca foi senão um acessório do seu poder espiritual. O primeiro era, sem dúvida, uma garantia para a independência do segundo. Mas o certo é que. acima da sua qualidade de soberano temporal, sempre esteve a de soberano espiritual, cuja autoridade ultrapassava os limites dos Estados Pontifícios, tornando-se mundial. E essa qualidade primordial í o que constitui a verdadeira razão de ser do Papado.

Em todo caso, prossegue Accioly, a soberania do Vigário de C'risto bastava para que se não discutisse a situação internacional da Santa Sé. Quando, porém, acrescenta o autor, Vitorio Emmanuele I se apoderou violentamente de Roma, em sctembro de 1870, a situação mudou: o poder temporal do papa desapareceu. Até então, internacional e juridicamente, só se considerava o papa no seu caráter de Chefe de um Estado (os Estados Pontificios): era este, propriamente, que possuía a qualidade de pessoa de direito internacional. Desapa:ecendo o F.stado (os Estados Pontifícios). extinguia-se, ipso facto, a personalidade intemacional. E. assim, começou a ser negada ao (hefe da Igreja Católica a condição que. sem exame mais detido. muitos consideravam como simples reflexo da qualidada de Chefe de Estado.

32 ACCIOLY, H. Há vinte e cinco anus... a personalidade intemacional do papa. Separada da: A Ordem, de.. 1930. p. 63-72. 


\subsection{Lei das (iarantias (1870-1929)}

Logo após a tomada de Roma, prossegue Accioly na obra citada, os homens do Estado italiano compreenderam a necessidade de dar satisfações aos milhões de católicos do mundo inteiro e de tranqüilizar as diversas potências influenciadas pelo Catolicismo, naturalmente inquietas com a nova situação criada ao Papado. Compreenderam, ao mesmo tempo. as conveniências de regularizar as relações do Estado italiano com a Santa Sé e de assegurar a esta, ou antes. ao exercício da sua função espiritual. a mais ampla liberdade de ação que fosse possivel. Dai a decretação da chamada Lei das Garantias, de 13 de maio de $1870 .^{33}$ que vai prevalecer até 1929, com a assinatura entre os dois países do Tratado de Latrão.

Essa lei, prossegue o autor na obra citada, ato unilateral do Parlamento italiano, nunca foi reconhecida pela Santa Sé, mas como que recebeu a aprovação ou aquiescência tácita dos Fstados estrangeiros c adquiriu importância internacional. Por ela, embora não se reconhecesse ao papa nenhum direito de sobcrania territorial, eram-lhe concedidas quase todas as prerrogativas dos soberanos ou chefes de estado: a inviolabilidade da pessoa, hon:as peculiares aos soberanos, imunidade de residência. direito ativo e passivo de legação. Além disso, a Lei das Garantias assegurava a independência absoluta do Santo Padre no exercício de sua missão espiritual. ${ }^{\circledR 4}$

Accioly, na obra citada, observa que, enquanto vários autores negavam sistematicamente que o papa pudesse ser pessoa do Direito Internacional, outros sustentavam que, em face da Lei das Garantias, o exercício do direito de legação e da faculdade, que nunca foi negada ao Soberano Pontífice, de celebrar concordatas, não se the poderia contestar a personalidade internacional. Quanto às concordatas, embora se reconhecesse que, historicamente, apresentavam formas distintas dos tratados dos antigos Estados Pontificios, observa-se com razão que elas constituíam contratos análogos aos tratados c eram celebradas entre as partes contratantes ou poderes absolutamente independentes. A verdade, entretanto, é que a personalidade jurídica do papa, a sua soberania internacional, não podia decorrer da Lei das Garantias. ${ }^{35}$

Alguns internacionalistas, prossegue Accioly na obra citada, no seu raciocínio, já o tinham entrevisto há alguns anos.

Gcorges Scheles, por exemplo. em 1917, declarando que o papa poderia ser considerado como uma pessoa do Direito Internacional, dizia:

\footnotetext{
33 ACCIOLY. H. Há vinte e cinco anos... a personalidade internacional do papa. Separada da: A ().dem. dé. 1930, p. 64-65.

Ibid., p. 64-65.

Ibid.. p. 65-66.
} 
Ele encama interesses de ordem especial, de natureza religiosa, interesses comuns a uma larga comunidade internacional e que chegaram a agrupar-se em torno de uma personificação especial c distinta dos Estados. ${ }^{36}$

F. acrescentava:

O Papado goza, tradicional e logicamente, para defender os interesses internacionais que encarna, de certas prerrogativas pertencentes aos sujeitos do direito internacional e, principalmente. do direito de legação passivo e ativo, complemento indispensável da competencia, ou, se prefirem, da soberania, necessária à execução dos fins da sua atividade especial. ${ }^{37}$

Realmente, argumenta Accioly na obra citada, a Igreja Católica agrupa interesses distintos e possui uma vontade capaz de os dirigir. O seu chefe, apesar de desaparecido o seu poder temporal. não passou a ser súdito de nenhum Estado. Nunca se lhe contestou a autoridade suprema em matéria religiosa. Forçoso era, pois, reconhecerthe a qualidade de poder soberano e personalidade jurídica própria. ${ }^{38}$

Não se diga que outras comunidades religiosas, acrescenta Hildebrando Accioly, estão ou estavam nas mesmas condições. A não ser a Igreja Católica, nenhuma realizou jamais, como ela, a universalidade ${ }^{39}$ de par com a unidade ${ }^{40}$ nenhuma goza da mesma independência, ${ }^{41}$ nem da mesma autoridade moral; ${ }^{42}$ nenhuma existe com organização tão perféita e tão disciplinada. ${ }^{13} \mathrm{O}$ seu caso é, verdadeiramente, único.

Concluindo seu pensamento, diz. Accioly na obra citada: o papa, com ou sem a Lei das Garantias, possuía personalidade internacional. Não se contesta, porém, que esta tinha caráter diferente da dos Estados. Basta assinalar que a sua soberania entre 1870 e 1929 era apenas de natureza espiritual. ${ }^{44}$ Essa soberania espiritual foi, na verdade, o fundamento das prerrogativas reconhecidas à Santa Se. ${ }^{45} \mathrm{E}$, ainda hoje, após o Tratado de Latrão, é nela que se baseia, principalmente, a autoridade soberana do chefe do Catolicismo. ${ }^{16}$

\footnotetext{
SCHELES, G. Revue Générale de Droit International Public, t. 24, p. 250.1917.

SCHELES, G. op. cit., p. 251.

ACCIOLY, H. op. cit., p. 66.

$\mathrm{O}$ grifo é nosso.

$O$ grifo é nosso.

O grifo é nosso.

O grifo é nosso.

O grifo é nosso.

O grifo é nosso.

$\mathrm{O}$ grifo é nosso.

ACCIOLY, H. op. cil.. p. 67.
} 
Nisso, tranqüiliza Accioly. estão de acordo muitos de entre os mais ilustres internacionalistas contemporâncos, tais como:

Yves de la Brière:

(...) é de caráter unilateral e subsiste pela própria natureza das coisas, ainda que na ausência de garantias satisfatórias e aceitáveis. O papa é soberano. ${ }^{47}$ porque não depende do poder legislativo, judiciário ou coercitivo de nenhum Estado temporal e porque se acha habilitado a tratar, de igual para igual, com todos os Estados e governos, na comunidade do direito das gentes. ${ }^{48}$

Louis Le Fur afirma, com justeza, que a soberania da Santa Sé “(..) é funduda sobre motivos juridicos e sociológicos permanentes, sohre uma realidade social que dura há 2000 anos e não sobre um tratado que data de alguns dias e que tem todas as probabilidades de desaparecer antes da própria Igreja" 49

Delos, apoiando, aliás, o ponto de vista de Le Fur, observa:

Creia ou não o jurista na afirmação da Igrcja sobre a sua natureza e a origem do seu poder, um fato lhe basta: a Igreja é uma sociedade humana, perfeita, livre, senhora de si mesma e de seus destinos. sob a autoridade do chefe que ela escolhe; o jurista tem diante de si um grupo internacional dotado da personalidade moral natural. ${ }^{50}$

Na boa companhia desses autores, Accioly afirma na obra citada que "(..) a ausência do poder temporal não implicava, absolutamente, na auséncia da soberania" 51

Em respaldo a essa conclusão, Accioly, na obra citada, cita novamente Louis Le Fur, que, por sua vez, afirma:

A soberania é um direito de decisão em última alçada, um direito de mando, que se exerce sobre pessoas e não sobre territórios. O território poderá ser apenas, em relação à soberania, um elemento material sobre o qual esta, de alguma sorte. se apóia. Ele servirá para fixar os limiles até onde se poderá exercer a soberania, pois que a soberania temporal, divisivel no espaço, é repartida entre os diversos

\section{O grifo é nosso.}

48 DE LA BRIËR, Y. La question romaine u le traité de Latran. Revié de Droit International. 1. 3, 1929. p. 24.

49 LE FUR, L. Le Saint Siėge e le droit intemational. Revue de Droit International, t. 3, p. $157,1929$. Consulte, tambèm: LE FUR, L. Le Saint Siége et le droit des gens. Paris. 1930; GOYAU, C. L'Église catholique et le droit des gens. Recueil des Cours. p. 123 ss., 1925.

s0 DELOS, J. T. Le Traité de l atran et la situation nouvelle de la Papaute. Revue de Droil Imtornational, t. 36. 3. série, 1. 3, 1929, p. 457.

sI ACCIOI.Y. H. op. cit. p. 68. 
Estados do globo. O território indica, assim, os indivíduos que dependem de cada soberania. Mas o fato é que, ainda para o Estado, potência temporal, a soberania é, antes de tudo, um poder sobre pessoas ${ }^{5 ?}$. antes que sobre coisas ou o território. Destarte, a soberania do Estado, na essência, pode ser considerada da mesma natureza do que se atribui à Santa Sé ou ao papa. ${ }^{53}$ A única difcrença é, por assim dizer, de proporção e resulta da diferença de fins. ${ }^{54}$

Em seguida, Accioly cita, na obra em apreço, o papa Pio XI, mostrando assim a coincidência de pontos de vista com a sua compreensão sobre a natureza juridica sobre a autêntica soberania do Sumo Pontifice e, portanto, da Santa Sé:

Estão em presença, se não dois Estados, certamente duas soberanias, no sentido amplo do termo, isto é, plenamente perfeitas, cada uma em sua esfera necessariamente determinada pelos respectivos fins - ao que é bastante acrescentar que a dignidade objetiva dos fins determina não menos objetiva e necessariamente a absoluta superioridade da Igreja.

2.3. Os Acordos de Latrão (1929) ${ }^{56}$

No dia 11 de fevereiro de 1929, relata Accioly na obra citada, foram solenemente assinados, no Palácio de Latrão, em Roma, pelo cardeal Pietro Gasparri, em nome da Santa Sé, e pelo primeiro-ministro italiano, Benito Mussolini, em nome da Itália,

\author{
O grifo ć nosso. \\ O grifo é nosso. \\ LE FUR, L. op. cit. p. 57-58. \\ ACTA Apostolicae Sedis. Alocução de Pio XI, 30 maiu 1929. p. 30.
}

Cr. ACCIOLY, H.; SILVA, G. E. Manual de direito internacional público. São Paulo: Saraiva, 2002. p. 173-178; STORIA della Chiesa. I cattolici nel mondo contemporaneo (1922-1928). Milano: Ed. Paoline, 1991. v. 23, p. 58-63. Para aprofundamento do tema: ANZILOTTI, D. La condizione giuridica internazionale della Santa Sede in seguito agli accordi del I.aterano. Rivista di Diritto Internazionale. v. 4 , fasc. 2, p. 165 ss.. 1929.; D'A VACK, A. P. La qualifica giuridica della Santa Sede nelle stipulazioni del trattato lateranense. Rivista di Diritto Internazionale, p. 8.3 ss. c p. 217 ss.,. 1935; GESTOSO TUDELA, L. La independencia de la Santa Sede y el Tralado de Lelian, Murcia: [s. n.]. 1930. A.A.V.V. Chiesa, azione cattolica e fascismo nell'Italia settentrionale durante il pontificato di Pio XI (1922-1939), Vita e Pensiero, 193I, Ave. Roma, 1983. BERSELLI. A. Documenti sulle trattative per la soluzione della questione romana nel 1861. Archivo storico italiano, n. 113, p. 73-100. 1955; ACTA Apostolicae Sedis... v. 21. p. 209-294: o Tratado de Latrão. quanto à parte concordatária. scrá modificado através da assinatura do Acordo de 18 de fevereiro de 1984 entre a liália e a Santa Sé. Para aprofundamento: Concordato 1984: premisse e prospettive: Quatroventi. Urbino. 1985: COCHAUX, H. Le Pape e l'Italie. les Accords du I atran. Paris: Beauchesne, 1929; BALDASSARI, A. Il Tratlato del laterano. Bari: [s. n.], 1930. Brochure de 41 p.: BAUDRILLART, M. et al. Les Accords du Latran. Paris: Spes, 1930; DELOS, J. T., p. 452-478: TOSTAIN, L. Le traité politique du Latran et la personnaliti en droit puhlic. Paris: Spes. 1930. 
dois documentos internacionais que se tornaram conhecidos e tiveram enorme repercussão mundial, sob a denominação de Acordos de Latrão.

Explica esse autor que esses atos constam de um tratado politico e de uma concordata $^{57}$ - a segunda considerada pela Santa Sé, conforme se declara no respectivo preâmbulo, como o complemento necessário do primeiro. ${ }^{58}$

Salvatorelli ${ }^{59}$ observa, porém. que a Conciliação (naturalmente entre a Santa Sé e o Estado italiano) era, na verdade, o fato mais importante da política concordatária, que no tratado previa dois momentos: o reconhecimento da completa independência da Santa Sé sobre o seu território e o restabelecimento de relações diplomáticas. ${ }^{60}$

As origens mais remotas dos Acordos de Latrão se rclacionavam à Questão Romana, por um lado, enquanto que suas origens mais recentes, por outro lado, consistiam no desejo da Santa Sé e da Igreja italiana de reverter uma situação insustentável, aproveitando-se da fase nacionalista do Governo Mussolini (que acabou logo, aliás, em 1931), disposto agora a conferir à Igreja a melhor posição possível, em vista da expansão italiana no mundo. Para iniciar as tratativas com o Estado italiano, a Santa Sé fazia apenas duas exigências: a concessão de um território à Santa Sé e o reconhecimento dos efeitos civis do matrimônio religioso. ${ }^{61}$ Porém, o problema mais espinhoso passou a ser não o matrimônio com efeitos civis, mas sim a questão da educação coletiva da juventude devido ao avanço do regime de Mussolini pelas vias do totalitarismo. Por isso, as tratativas sofreram duas interrupções, em 1927 e 1928. As negociações foram reiniciadas e em 20 de agosto de 1928 o projeto final dos Acordos já estava pronto. Superada a fase de discussão política pela Itália, os Acordos de Latrão estavam prontos para serem assinados no dia 11 de fevereiro de $1929 .{ }^{62}$

$\mathrm{Na}$ verdade, os Acordos de Latrão compreendiam três documentos: o tratado. a concordata ${ }^{63}$ e a convenção financeira. Através do Tratado, o Estado italiano reconhecia a independência e a soberania da Santa Sé no território, ainda que minúsculo, denominado Estado da Cidade do Vaticano. A soberania do novo Estado era, contudo, tão completa que the era reconhecida até a faculdade de ter representantes dos Estados mesmo no caso que esses estivessem em guerra com o Fstado italiano. A Santa Sé, por sua vez. dava por completamente encerrada a Questão Romana e reconhecia o Estado italiano

57 Essa será renovada em 18/02/1989, como, aliás, foi dito anteriormente.

58 Cf. ACCIOLY. H. op. cit., p. 69-72.

59 SALVATORELLI, L. Pio XI e la sua eredità pontificale. Torino: Einandi, 1939. p. 127.

${ }^{60}$ Cf. STORIA della Chiesa. op. cit.. p. 58.

61 Idem, loc. cit.

62 STORIA della Chiesa, op. cit., p. 59

63 Bem mais tarde, em 18/02/1984, essa concordata scrá substituída por uma nova, durante o governo de Bettino Craxi e enquanto era Secretario do fistado o Cardeal Casaroli. 
regido pela dinastia dos Savóia e nos limites territoriais existentes. Uma troca dos respectivos diplomatas deveria sancionar tais acordos. ${ }^{64}$

\subsection{Elementos mais relevantes do Tratado de Latrão (1929)}

Uma vez que o Estado da Cidade do Vaticano é fruto do Tratado de Latrão, faremos agora referência aos elementos mais relevantes do Tratado.

Inicialmente, no Prólogo do mencionado Tratado, afirmam-se, dentre outras, as scguintes razões para a criação do Estado da Cidade do Vaticano:

assegurar à Santa Sé. de modo estável, uma condição de fato e de direito que lhe garanta independência absoluta para o cumprimento da sua alta missão no mundo;

- assegurar à Santa Sé independência absoluta e visível; garantir-lhe uma soberania indiscutivel também no campo internacional; vislumbrou-se a nccessidade de constituir, com modalidades particulares, a cidade do Vaticano, ${ }^{66}$ reconhecendo sobre a mesma a propriedade, o poder total, exclusivo, absoluto, bem como a jurisdição soberana da Santa Sé. ${ }^{67}$

Em outras palavras, o Tratado de Latrão, que, no seu Proêmio, reconhece o Estado da Cidade do Vaticano como sendo aquele determinado turritório sobre o qual a Santa Sé goza de independência política absoluta interna e sobretudo no campo internacional, necessária para a realização de sua missão de evangelização no mundo.

Declara o Tratado de I atrão, no seu art. $2^{\circ}$, reconhecer “(...) a soberania da Santa Sé no dominio internacional, com os atributos inerentes a sua natureza, de conformidude com a sua tradição e as exigências da sua missão no mundo" 68

Enquanto a Santa Sé é pessoa moral, ou seja, possui uma natureza religiosa e humanitária que antecede em pelo menos quinze séculos o aparecimento do próprio Estado Moderno, em 1648 (Tratado de Vestfália), e reconhecida enquanto tal pelo Direito Positivo Internacional, o que lhe dá, também, a condição de sujeito soberano de Direito Internacional. o Estado da Cidade do Vaticano, por sua vez, é pessoa jurídica internacional pública, pois surgiu de um acordo bilateral celcbrado no Tratado de I.atrão

STORIA della Chiesa. op. cil.. p. 60.

ACTA Apostolicae Sedis... p. 209.

O grifo é nosso.

ACTA Apostolicae Sedis... p. 209-210.

ACTA Apostolicae S.dis... p. 210. 
de 1929 - e, portanto, de Direito Internacional -, assinado entre a Santa Sé e o Estado italiano. Esse Tratado, no seu art. $3^{\circ}$ afirma o seguinte:

A Irália reconhece à Santa Sé a plena propriedade e o exclusivo e absoluto poder e jurisdição soberanos sobre o Vaticano como é atualmente constituido, com todas as suas pertinências e dotações, criando-se assim a Cidade do Vaticano para os fins especiais e segundo as modalidades mencionadas no presente Tratado. Fica claro, além do mais, que a Praça de São Pedro, mesmo fazendo parte da Cidade do Vaticano, continuará normalmente aberta ao público ¿ sujcita aos poderes de policia das autoridades italianas, as quais não ultrapassarão as escadas da Basilica; ainda que esta continue a ser destinada a culto público, abster-se-ào de subir e adentrar a referida Basílica, salvo quando convidados a intervir pela autoridade competente. ${ }^{69}$

Para que não haja dúvidas sobre o sentido dessas disposições, o art. $4^{\text {U do }}$ Tratado de Latrão esclarece: "A soberania e a jurisdição exclusiva que' a liália reconhece à Santa Sé sobre a Cidade do Vaticano, importa que, sobre a mesma, não cabe qualquer ingerência da parte do Governo Italiano e que ali não existe outra autoridade qui aquela da Santa Sé" 70

Artigo $5^{\circ}$ :

Para a execução do quanto está estabelecido no artigo precedente, antes da entrada em vigor do presente Tratado, o terrilório que constitui a Cidade do Vaticano deverá ser, aos cuidados do Governo Italiano, liberado de qualquer empecilho e de eventuais ocupantes $(\ldots)^{71}$

Artigo $6^{\circ}$ :

A Itália garantirá o fornecimento (...) à Cidade do Vaticano de: (...) adequada quantidade de água; (...) comunicação ferroviária com a rede ferroviária da Itália; (...) serviços telegráficos, serviços públicos: (...) sistemas de acesso ao Vaticano. $^{72}$

Artigo $7^{\circ}$ :

No território que circunda a Cidade do Vaticano. o Governo italiano se empenha a não permitir novas construções, que constituam introspecção, bem como demolir parcialmente,

\footnotetext{
69 ACTA Apostolicae Sedis..., p. 210-211.

70 ACTA Apostolicae Sedis... p. 211.

${ }^{71}$ Id., loc. cit.

72 Id. Ibid., p. 212.
} 
com o mesmo fim, aquelas existentes junto a Porta Cavalleggeri, Via Aurélia e Viale Vaticano. Em conformidade às normas de direito internacional, é proibido aos vcículos aéreos de qualquer tipo sobrevoar o território do Vaticano. Na Praça Rusticucci e nas zonas adjacentes às Colunas; lá onde não se estende a extraterritorialidade tratada pelo art. 15, qualquer mudança edilícia ou viária que possa interessar à Cidade do Vaticano se fará de comum acordo. $^{73}$ inviolável" 74

$\mathrm{O}$ art. $8^{\circ}$ declara a pessoa do Suberano Pontífice como “(...) sagrada $e$

Conforme se estipulou no art. $9^{\circ}$ do Tratado de Latrão e de acordo com os preceitos do direito internacional, são submetidos à soberania da Santa Sé as pessoas que têm residência fixa na Cidade do Vaticano. Tal residência não se perde pelo simples fato de permanência temporária em outro lugar.

No art. 12, o Tratado de Latrão afirma que “(...) a Itália reconhece à Santa Sé o direito de representaçâo diplomática, ativo e passivo, segundo as regras gerais do direito internacional, 75

Segundo o mesmo artigo, "os diplomatas estrangeiros acreditados junto $\dot{a}$ Santa Sé continuarão a gozar, na liália, de todas as prerrogativas e imunidades que, de acordo com o direito internacional, são concedidas aos agentes diplomáticos" 76

Além disso, a Itália se compromete, explicitamente "(...) a respeitar sempre e em qualquer caso a liberdade de correspondencia entre todos os Estados, inclusive os beligerantes, e a Santa Sé, e vice-versa"

Ainda do art. 12 do Tratado de Latrão consta a declaração de que "o Núncio Apostólico junto ao Governo Italiano será o Decano do Corpo Diplomático, conforme o direito costumeiro reconhecido pelo ato de 9 de junho de 1815, do Congresso de Viena" 7 ?

Os arts. 13, 14, 15 e 16 do Tratado de Latrão referem-se ao reconhecimento da propriedade da Santa Sé sobre diversos imóveis, situados em Roma ou nos arredores, os quais gozarão das imunidades reconhecidas pelo direito internacional às residências dos agentes diplomáticos dos Estados estrangeiros. ${ }^{78}$

\footnotetext{
ACTA Apostolicae Sedis... p. 212-213.

Id. Ibid., p. 213.

ACTA Apostolicae Sedis... p. 215.

Id., loc. cit.

Id., loc, cit.

ACTA Apostolicae Sedis... p. 215-210.
} 
O art. 20 do Tratado de Latrão permite que as mercadorias procedentes de países estrangciros e destinadas à Cidade do Vaticano transitem pelo território italiano com plena isenção de dircitos aduaneiros ou impostos de entrada. ${ }^{79}$

Diz o art. 21 que "todos os cardeais gozam, na Itália, das honras devidas aos principes de sangue e acrescenta que os residentes em Roma, ainda que fora da Cidade do Vaticano, são, para todos os efeitos, cidadãos desta última" ${ }^{80}$

$\mathrm{O}$ mesmo artigo consigna disposições tendentes a assegurar a livre reunião dos conclaves, assim como dos Concílios presididos pelo papa. ${ }^{81}$

$\mathrm{O}$ art. 22 do Tratado de Latrão contém uma estipulação curiosa: é a delegação à Itália, pela Santa Sé, do poder de jurisdição do novo Estado, em determinadas hipóteses. Assim, diz esse artigo:

A pedido da Santa Sé, e por delegação que poderá ser dada para cada caso particular ou a título permanente, a Itália providenciará, no seu território, sobre a punição dos delitos que tenham sido cometidos na Cidade do Vaticano, salvaguarda ao autor do delito se tiver refugiado no território italiano, caso em que ela procederá imediatamente contra ele, de conformidade com as leis italianas. ${ }^{82}$

O mesmo artigo acrescenta que:

A Santa Sé entregará ao Estado italiano as pessoas que. depois de terem cometido atos considerados delituosos pelas leis dos dois Estados, se refugiarem na Cidade do Vaticano ou em algum dos imóveis que lhe pertencem e que, segundo 0 art. 15, gozam de imunidades diplomáticas. ${ }^{83}$

Artigo 23:

Para a execução na Itália das sentenças emanadas pulos tribunais da Cidade do Vaticano, aplicar-se-ão as normas do direito internacional. ${ }^{\text {}}$

No art. 24 do Tratado de Latrão figura a declaração de que "(...) a Cidade do Vaticano será sempre, e em qualquer cuso, considerada território neutro $e$ inviolável" 85

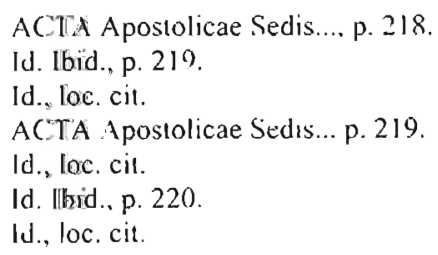


Portanto. essa neutralidade é garantida por disposição expressa do Tratado, nos artigos acima citados.

O art. 26 do Tratado de Latrão, além de reafirmar o quanto dito sobre as razõus para a criação do Estado do Vaticano, a saber: liherdade e independência no governo pastoral da Diocese de Roma, da Igreja Católica na Itália e no mundo, declara também:

Resolvida. de maneira definitiva e irrevogável. a Questão Romana, surgida em $1870 \mathrm{com}$ a anexação de Roma ao Reino da Itália sob a dinastia da Casa de Savóia, com Roma, capital do Estado italiano, enquanto, por sua vez, a Itália reconhece o Estado da Cidade do Vaticano sob a soberania do Sumo Pontífice. ${ }^{86}$

Isto posto, Accioly concluiu que não pode mais haver dúvida alguma quanto à personalidade jurídica internacional da Santa Sé ou do seu chefe, o papa. ${ }^{87}$

A partir desses elementos. algumas conclusões são necessárias:

1. O Estado da Cidade do Vaticano, ainda que minúsculo. possui todos os caracteres formais de um Estado soberuno e sobre o qual o pupa exerce plena soberania.

2. Não pode haver mais dúvida quanto à personalidade jurídica da Santa Sé ou do seu chefe, o papa.

3. Foi só a necessidade de se dar base material à soberania espiritual do papa, de se lhe conceder uma garantia de direito público internacional capaz de the assegurar a completa independência, que determinou a criação da soberania territorial da Santa Sé, ainda que sobre uma área mui restrita. ${ }^{88}$

4. A Santa Sé e o Estado da Cidade do Vaticano são dois distintos sujeitos internacionais. Embora possuum também uma intima relação de "união pessoal", 89 há várias teorias sobre isso na doutrina, como se verá a seguir, dado ser o Sumo Pontifice o Poder Supremo daqueles dois sujeitos internacionais.

5. A personalidade juridica internacional compete exclusivamente à Santu Sé, seja no plano interno -.. o próprio ordenamento canônico, scja no plano internacional - os Tratados, Concordatas.

\footnotetext{
86 $\quad$ ACTA Apostolicae Sedis... p. 219.

O grifo é nosso.

ACCIOLY, H. op. cit., p. 72.

Explicar-se-á melhor no item 3 - Elemento de complementaridade entre a Santa Sé e o rstado da Cidade do Vaticano.
} 
6. Como discerniu o ex-presidente das Nações Unidas, Dag Hammerskjöld, em (ienebra, no verão de 1957: "Quando cu solicito uma audiência no Vaticano. não vou visitar o rei da (idade do Vaticano, mas o chefe da Igreja Católica" 90

Assim, ele distingue de fato ambos os conceitos, ou seja, o da Santa Sé e o do Estado da Cidade do Vaticano, além de evidenciar, também, a relação de "união pessoal" que liga os dois entes internacionais. ${ }^{91}$

Fm sintese, sobre a identidade do Estado da Cidade do Vaticano, poder-seia dizer o seguinte: é fruto do Tratado de Latrāo de 1929, entre a Santa Sé e o Reino da Itália; por isso a sua origem é de Direito Positivo Internacional. Sua finalidade é a de "assegurar à Santa Sé. de modo estável. uma condição de fato e de direito que the garanta independencia absoluta para o cumprimento da sua alta missão no mundo";"92 "assegurar à Santa Sé independência indiscutivel também no campo internacional; vislumbrou-se a necessidade de constituir, com modalidades particulares, a (idade do Vaticano, reconhecendo sobre a mesma a propriedade, o poder total, exclusivo, absoluto, bem como a jurisdição soberana da Santa Sé" ${ }^{23}$ Portanto, a finalidade do Estado da Cidade do Vaticano é de constituir-se em base territorial ou material para abrigar a Santa Sé, que é, essencialmente, uma soberania espiritual, cujo titular é o Papa; a fim de que ele possa gozar de independência política absoluta interna es sobretudo, no campo internacional, necessária para a realizaçăo de sua missão de evangelização no mundo. Portanto, a existência do Estado da Cidade do Vaticano tem como única finalidade assegurar a soberania da Santa Sé em relação aos demais Estados (é um instrumento de soberania da Santa Sé). sem, contudo, se identificar com aqueles. É Pessoa Jurídica de Direito Internacional Público, pois é plenamente um Estado, isto é. possui todas os caracteres formais de um Estado soberano sobre o qual o papa exerce plena soberania. A existência, contudo, do Estado da Cidade do Vaticano é mediante àquela da Santa Sé, ou seja, com "fins especiais" ou, em outras palavras, do ponto de vista político-territorial, a missão espiritual da Igreja Católica. De modo que é sempre a Santa Sé, com a sua mencionada Personalidade Juridica Internacional, a quem compete representar, exclusivamente, tanto a Igreja Católica quanto o Estado da Cidade do Vaticano, no plano nacional e internacional. O papa é, assim, a Suprema Autoridade desses dois últimos e a relação que se estabelece entre a Santa Sé e o Estado da Cidade do Vaticano é chamada de Identidade Pessoal ou União Pessoal, vale dizer, o papel de "chefe" comum da Santa Sé e

\footnotetext{
SALVADOR, C. C.; EMBIL, J. M. U. Dicionário de dreito camónico. São Paulo: Loyola, 1993, p. 676. Id., loc. cit.

Tratado de Latrão de 1929: Acta Apostolicae Sedis. Hocução de Pio XI. 30 de maio de 1929. p. 209.

Tratado de Latrão de 1929, op. cit., p. 209-210.
} 
da Cidade do Vaticano é exercido pela mesma pessoa, a saber, o papa. O papa é. então, a instância suprema da Santa Sé e do Estado da Cidade do Vaticano.

\section{Elemento de complementaridade entre a Santa Sé e o Estado da Cidade do Vaticano}

A complementaridade essencial entre a Santa Sé e o Listado da Cidade do Vaticano ucorre por muio da Identidade Pessoal ou União Pessoal, pela qual o papa é a Suprema Autoridade da Santa Sé e do Estado da Cidade do Vaticano. Identificação Pessoal ou União Pessoal significa, em outras palavras, que o Ofício da Suprema Autoridade das duas instituições é exercido pela mesma pessoa, a saber, o Bispo de Roma, ou seja, o papa. Portanto, o papa, ou Bispo de Roma, além de Chefe e Supremo detentor do Ofício da Sé Apostólica. é também soberano do Estado da Cidade do Vaticano.

A soberania territorial do Estado da Cidade do Vaticano existe unicamente para abrigar a soberania espirituál da Santa Sé e de seu titular, o papa. Aquela, portanto. está subordinada a esta última. A soberania espiritual da Santa Sé, contudo, é íntegra e atuante. mesmo se, eventualmente, vier a perder sua base territorial.

Enquanto pessoas internacionais, tanto a Santa Sé como o Estado da ('idade do Vaticano são membros de pleno direito da Comunidade Internacional dos Fstados c das Organizações Intergovernamentais.

Ambos participam de conferências e subscrevem ou aderum a convênios internacionais, segundo o status da sua participação, exercendo os mesmos direitos que os outros Estados-membros, em perfeita paridade com todos eles.

\section{Elementos de distinção entre a Santa Sé e o Estado da Cidade do Vaticano}

No sentido estrito e especial, o termo Santa Sé Apostólica designa somente o Romano Pontifice, quer dizer, o Ofício ou a Função do papa; ou, em outras palavras, designa o Papado, o Primado Romano e a sua pessoa.

Para os propósitos deste artigo, convím ressaltar mais o último sentido do termo Santa Sé, ou seja, o seu significado estrito e especial, vale dizer, a pessoa e a função do papa, que aparece aqui enquanto o titular em exercício da Santa Sé enquanto Órgăo Supremo de direção da Igreja Católica.

A Santa Sé é pessoa moral, porque não recebc sua personalidade e sua existència jurídica de algum ordenamento temporal ou territorial, mas, sim, diretamente de seu fundador. Jesus Cristo. Por isso, a Santa Sé é chamada, tambím, de pessoa "préjurídica", porque nasceu antes do próprio ordenamento jurídico, que, por sua vez, daria fundamento a pessua jurídica. Nesse sentido, a Santa Sé é pessoa de natureza espiritual, 
religiosa e humanitária, isto é, emana de um Direito inerente a sua própria natureza, ou seja, que não procede dos meios institucionais característicos do regime democrático. Em outras palavras, procede do Direito Divino.

A Santa Sé, portanto, é pessoa espiritual, dotada de Personalidade Jurídica de Direito Internacional Público, cujo seu titular é o papa.

O Estado da Cidade do Vaticano, por sua vez, é fruto do Tratado de Latrão de 1929, entre a Santa Sé e a Itália, e, por isso, é Pessoa de Direito Positivo Internacional.

Os agentes diplomáticos que representam o Sumo Pontífice, no exterior, representam somente a Santa Sé, a não ser que, por delegação especial, the seja dado também representar o Fstado do Vaticano. ${ }^{94}$

O Núncio Apostólico, que possui status de embaixador, representa a Santa Sé. e não o Estado da Cidade do Vaticano perante os Estados com os quais mantém relações diplomáticas e perante as Igrejas presentes no território de cada nação. A sua função está regulamentada no Código de Direito Canônico, Cân. 362-367.9.

Após o Tratado de Latrão, os documentos internacionais eram subscritos tanto em nome da Santa Sé como em nome do Estado da Cidade do Vaticano. Essa práxis só mudou a partir de 1957, quando a Santa Sé, unicamente, assumiu a dupla representação.

A diferença, portanto, de sujeito internacional entre a Santa Sé e o Estado da Cidade do Vaticano deverá ser deduzida da finalidade da representação concreta assumida em cada caso.

Apesar da dupla natureza de representação internacional, esta não é igual nem em importância. nem em atividade: a primordial é a correspondente à Santa Sé enquanto órgão supremo da Igreja católica Universal.

Somente a Santa Sé mantém representantes perante os Organismos Internacionais.

O Estado da Cidade do Vaticano, na mente do Tratado de Latrão, foi criado com um fim mediato ao da Santa Sé, com "fins especiais", vale dizer, viabilizar, do ponto de vista politico-territorial, a missão espiritual da Igreja Católica. ${ }^{96}$

É a Santa Sé quem celebra acordos (concordatas, mediações) com os Fstados signatários.

94 ANZILOTTI, D. La condizione giuridica internazionale della Santa Sede in seguito agli accordi del Laterano. Rivista di Diritto Internazionale, 1. 4. fasc. 2. p. 165 ss., 1929.

95 SALVADOR, C.C.: EMBIL, J.J. op. cit., p. 513.

96 ANZILOTTI, D. op. cit., p. 217. 
A Cidade do Vaticano é um organismo estatal que apresenta as mesmas características próprias de um Estado, ou seja. com os seus elementos materiais, território, população, autonomia de governo próprio. exército, fins a serem perseguidos.

\section{Conclusão}

Existe, portanto, uma relação ou articulação triangular entre a lgreja Católica, a Santa Sé e o Estado da Cidade do Vaticano. Aqueles dois primeiros conceitos nasceram simultancamente, enquanto pessoas morais, por vontade direta de Deus, isto é, através de Jisus Cristo. O Senhor Jesus, por sua vez, colocou Pedro e, por conseguinte, seus sucessores, os Papas, como Cabeça ou Suprema Autoridade da Igreja Católica. A Função Petrina ou Suprema Autoridade da Igreja Católica chamar-se-á Santa Sé, que representará esta última tanto no plano nacional quanto no internacional. A Santa Sé, por sua vez, enquanto pessoa soberana espiritual, mora ou tem o seu domicílio em um território denominado Estado da Cidade do Vaticano. que lhe assegura estabilidade e independência política, absoluta e visível em relação aos demais Estados: ou. em outras palavras, no Estado da Cidade do Vaticano reside o papa. que é a Suprema Autoridade da Igreja Católica e do Estado da Cidade do Vaticano. A Santa Sé está por Suprema Autoridade da Igreja Católica. O Estado da Cidade do Vaticano é apenas um território. Portanto, nunca o "Vaticano" pode ser sinônimo de Governo Central da Igreja Católica, vez. que não é pessoa, mas, sim, um ente estatal ou, simplesmente, um território.

São Paulo, dezembro de 2005.

Referências

ACCJOLY, H. Há vinte e cinco anos... a personalidade internacional do papa. Separada da: $A$ Ordem, dez. 1930, p. 63-72.

ACCIOLY, H.; SILVA, G. E. Manual de direito internacional puiblico. São Paulo: Saraiva, 2002.

ANZILOTTI. D. La condizione giuridica internazionale della Santa Sede in seguito agli accordi del Laterano. Rivistu di Diritto Internazionale, v. 4. fasc. 2, p. 165 ss., 1929.

CÓDIGO di Direito Canônico (CIC). Tradução em língua portuguesa da Conferência Nacional do Brasil, São Paulo: Loyola, 1983.

DE LA BRIĖRE, Y. La question romaine et le traité de Latran. Revue de Droit International, t. 3 , 1929. 
DELOS, J. T. Le Traité de Latran et la situation nouvelle de la Papauté. Revue de Droit International. t. 36, 3. série, t. 3, 1929.

LE FUR, L. Le Saint Siége e le droit international. Revue de Droit International, t. 3. 1929.

Llano CIfUENTES, R. Curso de Direito ('anônico. São Paulo: Saraiva, 1971.

SALVADUR, C.C.; EMBIL. J.M.U. Dicionário de Direito Canônico. Săo Paulo: Loyola, 1983.

SALVATORELLI. L. Pio XI e la sua eredità pontificale. Torino: Einandi, 1939.

SCHFLES, G. Revue Générale de Droit International Public, 2. 24, 1917.

STORIA della Chiesa. I cattolici nel mondo contemporaneo (1922-1928). Milano: Ed. Paoline, 1991. v. 23.

WILSON, L. G. A prática e o status da intervenção e da não-intervenção no direito internacional contemporâneo. Revista de Informação Legislativa, Brasília, v. 20, n. 79.

7.IMMERMANN, M. Organisation internationale (Fin du Moyen Age). Recueil des Cours, v. 2 , 1933.

Documentos

ACTA Apostolicae Sedis. Alocução de Pio XI, 30 maio 1929.

CONCÍlio VATICANO II, Parte II, Cap. V, n. 89.

JOÃO PAULO II. Discurso ao Corpo Diplomático acreditado junto à Santa Sé, de 1995.

GAUDIUM et Spes, 76.

TRATADO de Latrão de 1929: Acta Apostolicae Sedis. Alocução de Pio XI. 30 de maio de 1929. p. 209. 